\title{
Detection and quantification of enteric pathogens in aerosols near open wastewater canals in cities with poor sanitation
}

Olivia Ginn ${ }^{1}$, Lucas Rocha-Melogno ${ }^{2}$, Aaron Bivins ${ }^{3}$, Sarah Lowry ${ }^{1}$, Maria Cardelino ${ }^{1}$, Dennis Nichols ${ }^{4}$, Sachi Tripathi ${ }^{5}$, Freddy Soria ${ }^{6}$, Marcos Andrade ${ }^{7,8}$, Mike Bergin ${ }^{2}$, Marc A. Deshusses ${ }^{2}$, Joe Brown $^{9 *}$

${ }^{1}$ School of Civil and Environmental Engineering, Georgia Institute of Technology, Atlanta, GA, 30332, USA

${ }^{2}$ Department of Civil and Environmental Engineering, and Duke Global Health Institute, Duke University, Durham, NC, 27708, USA

${ }^{3}$ Department of Civil and Environmental Engineering and Earth Science, University of Notre Dame, Notre Dame, Indiana, 46656, USA

${ }^{4}$ Rollins School of Public Health, Emory University, Atlanta, GA, 30322, USA

${ }^{5}$ Department of Civil Engineering \& Centre for Environmental Science and Engineering, Indian Institute of Technology - Kanpur, India

${ }^{6}$ Centro de Investigación en Agua, Energía y Sostenibilidad, Universidad Católica Boliviana "San Pablo", La Paz, Bolivia

${ }^{7}$ Laboratory for Atmospheric Physics, Institute for Physics Research, Universidad Mayor de San Andres, La Paz, Bolivia

${ }^{8}$ Department of Atmospheric and Oceanic Sciences, University of Maryland, College Park, MD, USA

${ }^{9}$ Deparment of Environmental Sciences and Engineering, Gillings School of Global Public Health, University of North Carolina, Chapel Hill, North Carolina, 27599-7431, USA

*Corresponding author: Department of Environmental Sciences and Engineering, University of North Carolina, 135 Dauer Drive, Chapel Hill, NC, 27599-7431, USA. Tel: 404385 4579. Email: joebrown@unc.edu

\section{SYNOPSIS}

We detect and quantify molecular targets associated with important enteric pathogens in outdoor aerosols from cities with poor sanitation to assess the potential role of the aeromicrobiological pathway in enteric infection transmission in such settings.

\begin{abstract}
Urban sanitation infrastructure is inadequate in many low-income countries, leading to the presence of highly concentrated, uncontained fecal waste streams in densely populated areas. Combined with mechanisms of aerosolization, airborne transport of enteric microbes and their genetic material is possible in such settings but remains poorly characterized. We detected and quantified enteric pathogen-associated gene targets in aerosol samples near open wastewater canals (OWCs) or impacted surface waters and control sites in La Paz, Bolivia; Kanpur, India; and Atlanta, USA via multiplex qPCR (37 targets) and ddPCR (13 targets). We detected a wide range enteric pathogen-specific targets, some not previously reported in extramural urban aerosols, with more frequent detections of all enteric targets at higher densities in La Paz and Kanpur near OWCs. We report density estimates ranging from non-detects to $4.7 \times 10^{2} \mathrm{gc}$ per $\mathrm{m}^{3}$ air for targets including ST-ETEC, C. jejuni, EIEC/Shigella spp., Salmonella spp., norovirus, and Cryptosporidium spp. An estimated 25\%,76\%, and $0 \%$ of samples containing positive pathogen detects were accompanied by culturable E. coli in La Paz, Kanpur, and Atlanta, respectively, suggesting potential for viability of enteric microbes at the point of sampling. Airborne transmission of enteric pathogens merits further investigation in cities with poor sanitation.
\end{abstract}

NOTE: This preprint reports new research that has not been certified by peer review and should not be used to guide clinical practice. 

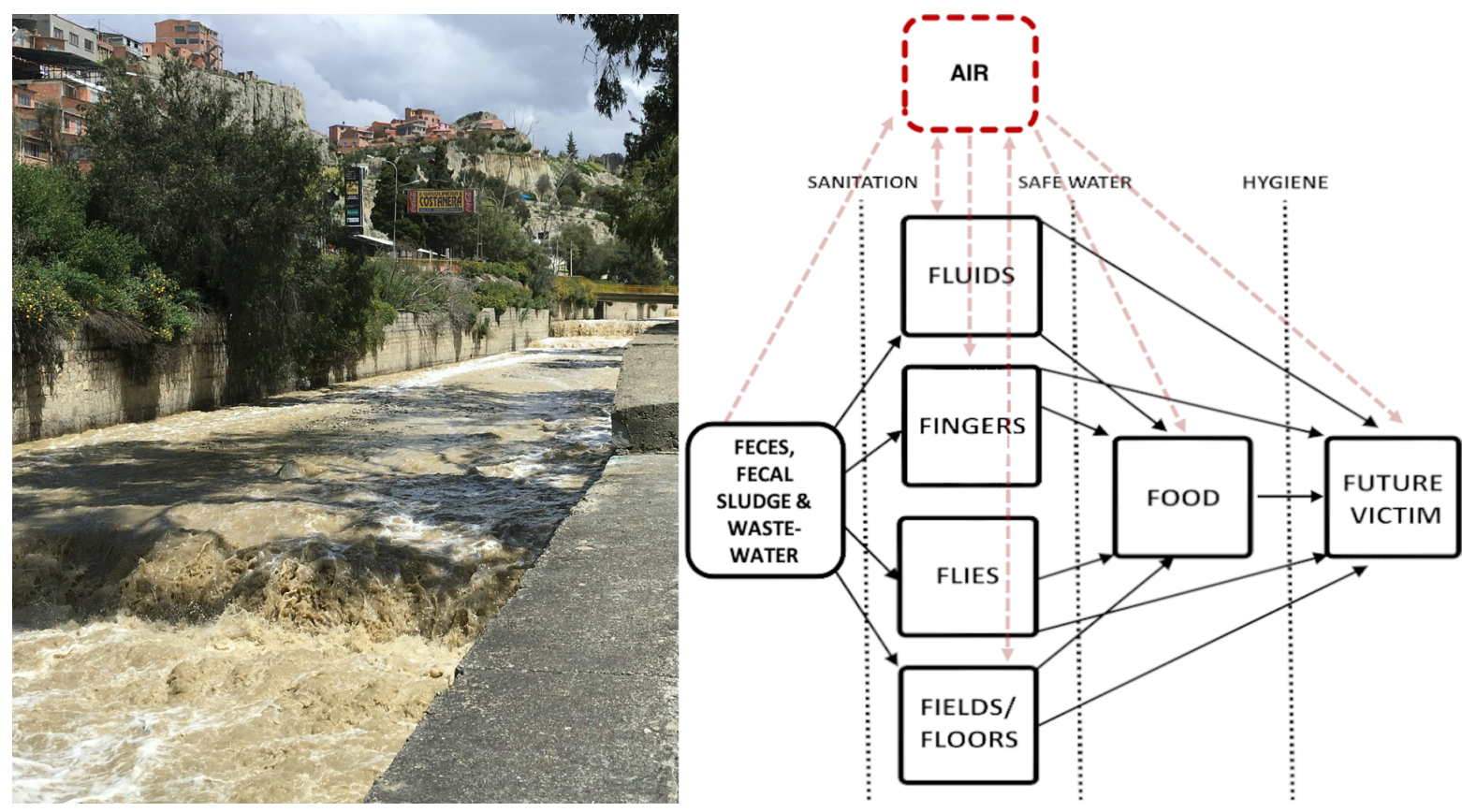

\section{INTRODUCTION}

With few exceptions, large cities in low- and middle-income countries (LMICs) have inadequate sanitation infrastructure $^{1-3}$. Unsafe water and sanitation enable the transmission of enteric pathogens from infected individuals to susceptible hosts via direct contact or through the environment in multiple interconnected pathways ${ }^{4,5}$. While a rich and rapidly growing body of literature describes microbial risks associated with direct or indirect exposure to fecal contamination in a wide variety of settings, relatively few studies have examined the potential for transmission of enteric pathogens via the aeromicrobiological pathway in highrisk settings. In cities in LMICs, the transport of enteric pathogens in aerosols may be possible due to a confluence of inadequate sanitation infrastructure resulting in concentrated flows of fecal wastes, a high disease burden resulting in high-risk waste containing human enteric pathogens, high population density, and environmental conditions that may be conducive to the aerosolization of concentrated fecal wastes. The aerosolization, transport, and deposition of microbial pathogens in cities lacking good sanitation could lead to exposure either through inhalation or through ingestion via other pathways (e.g., food, water, direct contact).

Aerosolization of biological material is known to be possible via several mechanisms including bubble bursting $^{6-8}$, evaporation, raindrop impaction ${ }^{9,10}$, and others ${ }^{11-14}$. The creation and persistence of bioaerosols can be associated with a range of variables related to environmental conditions and the built environment including rain events ${ }^{15-18}$, meteorological conditions ${ }^{19-21}$, urban surface waters and water features ${ }^{22-24}$, wastewater treatment unit processes that include mechanical mechanisms ${ }^{25,26}$, and other infrastructure. The mechanisms behind aerosolization and transport of microorganisms from liquid surfaces and the microbial effects on droplet lifetime have been well-characterized under controlled conditions ${ }^{6,7}$. Laboratory studies have revealed that bubbles in contaminated water surfaces may experience conditions manipulated by 
microorganisms, allowing for smaller, more numerous, and higher velocity droplets to transition from water to air $^{8}$. Similarly, it has been shown that plant pathogens may be released from plant surfaces through raindrop impaction and such releases escape the laminar boundary layer of leaves, allowing for longdistance, airborne transport of some pathogens ${ }^{9,10}$. Although the aerosolization and transport of plant pathogens and respiratory viruses (in indoor environments) have been studied, these phenomena and their implications are less well characterized for sanitation-related pathogens of public health importance.

Studies in high-risk, extramural (outdoor) settings in the USA and in other high-income countries have revealed that bioaerosols containing enteric microbes are common where concentrated fecal waste and one or more mechanisms for aerosolization exist. Enteric microbes in aerosols have been best characterized in ambient air surrounding wastewater treatment plants $^{27-37}$ and in the context of land application of biosolids ${ }^{38-48}$; several studies have examined bioaerosols surrounding composting facilities ${ }^{49,50}$, meat markets $^{51}$, urban areas ${ }^{52-54}$, and concentrated animal feeding operations ${ }^{55-57}$. The majority of such studies are based on detection of fecal indicator bacteria including members of the coliform group ${ }^{54,58}$, partly because the presence of important enteric pathogens is unexpected outside high-burden settings. A small number of studies have reported relative abundance of potentially pathogenic genera in $16 \mathrm{~S}$ sequencing studies $^{53,59}$. No previously reported studies have captured a broad range of enteric pathogens in bioaerosols from high-risk outdoor settings and no studies have conducted absolute quantification of enteric pathogens in bioaerosols in cities of LMICs, a necessary step in further assessment of the potential public health relevance of this poorly understood pathway of transmission. Based on previous literature on the presence of enteric microbes in aerosols from well-studied settings in wealthy countries, we hypothesized that aerosolized enteric pathogens could be present and quantifiable where urban sanitation is lacking. We assessed this hypothesis in two cities with poor sanitation and in one city with established and maintained wastewater infrastructure as a reference site.

\section{METHODS}

Sampling locations. We conducted sampling in Kanpur, India (May - July 2017); La Paz, Bolivia (March 2018, June 2018, March 2019, June and July 2019); and Atlanta, Georgia, USA (March 2018-January 2019). Kanpur has distinct dry (October to June) and rainy (July to September) seasons; we sampled from May to August to capture both periods. Similarly, we intentionally sampled in La Paz during both rainy (December to March) and dry (May to August) seasons.

Kanpur is densely populated (Nagar district: 4.6 million people, population density of 1500 persons $\left./ \mathrm{km}^{2}\right)^{60}$ with a majority of untreated industrial, agricultural, and sewage waste conveyed via a system of uncovered canals (open wastewater canals, OWCs) discharging to the Ganges River ${ }^{61,62}$. In La Paz, a network of rivers receive untreated sewage discharge, industry effluent, and stormwater runoff; most of the waterway flows in a series of engineered channels ${ }^{63,64}$, also characterized as OWCs. The largest of these is the highly impacted Choqueyapu River, flowing through central La Paz (population: 900,000, 900 persons $\left./ \mathrm{km}^{2}\right)^{65,66}$ where it is joined by tangential tributaries including the Orkojahuira, Irpavi, and Achumani rivers. In past studies, this river system and its basin - eventually flowing into the Amazon - has been shown to contain a diverse and rich array of enteric microbes indicating high levels of fecal contamination ${ }^{63,66,67}$. As a reference site, Atlanta is characterized by having an established and maintained subsurface wastewater 
infrastructure, although urban surface waters in Atlanta's watershed experience elevated levels of fecalassociated pathogens ${ }^{68-70}$ due to nonpoint source pollution and combined sewer overflows ${ }^{71,72}$. The city of Atlanta's population density is an estimated 1500 persons $/ \mathrm{km}^{273}$, though sampling locations near impacted streams were in suburban locations at lower than mean population density.

We identified 18 sites in Kanpur, 37 sites in La Paz, and 8 sites in Atlanta meeting the following criteria: (1) proximity to sources of bioaerosols $(<1 \mathrm{~km})$ containing enteric microbes, OWCs in the cases of India and Bolivia and impacted surface waters in Atlanta; (2) public and ground level accessibility; and (3) unintrusive to members of the community during multi-hour sampling events. In Kanpur, we selected a control site greater than $1 \mathrm{~km}$ away from known OWCs and located on the Indian Institute of Technology (IIT)-Kanpur's campus. The campus is a controlled private area with limited access to non-students and non-faculty, is less densely populated, has underground piped sewerage, and has a much lower animal presence. In La Paz, we identified two control sites $>1 \mathrm{~km}$ from known concentrated wastewaters or other contaminated sources: (1) Chacaltaya, a weather station and environmental observatory located at $5380 \mathrm{~m}$ in elevation and far from human habitation and (2) Pampalarama, an undisturbed site near the Choqueyapu headwaters. In Atlanta, we sampled at eight sites adjacent to impacted streams and rivers in Atlanta's watershed: the Chattahoochee River, Proctor Creek, Foe Killer Creek, and South Fork Peachtree Creek. Additionally, we sampled on the roof of our laboratory and at ground level on Georgia Tech's campus (located in Midtown Atlanta), $>1 \mathrm{~km}$ from surface waters.

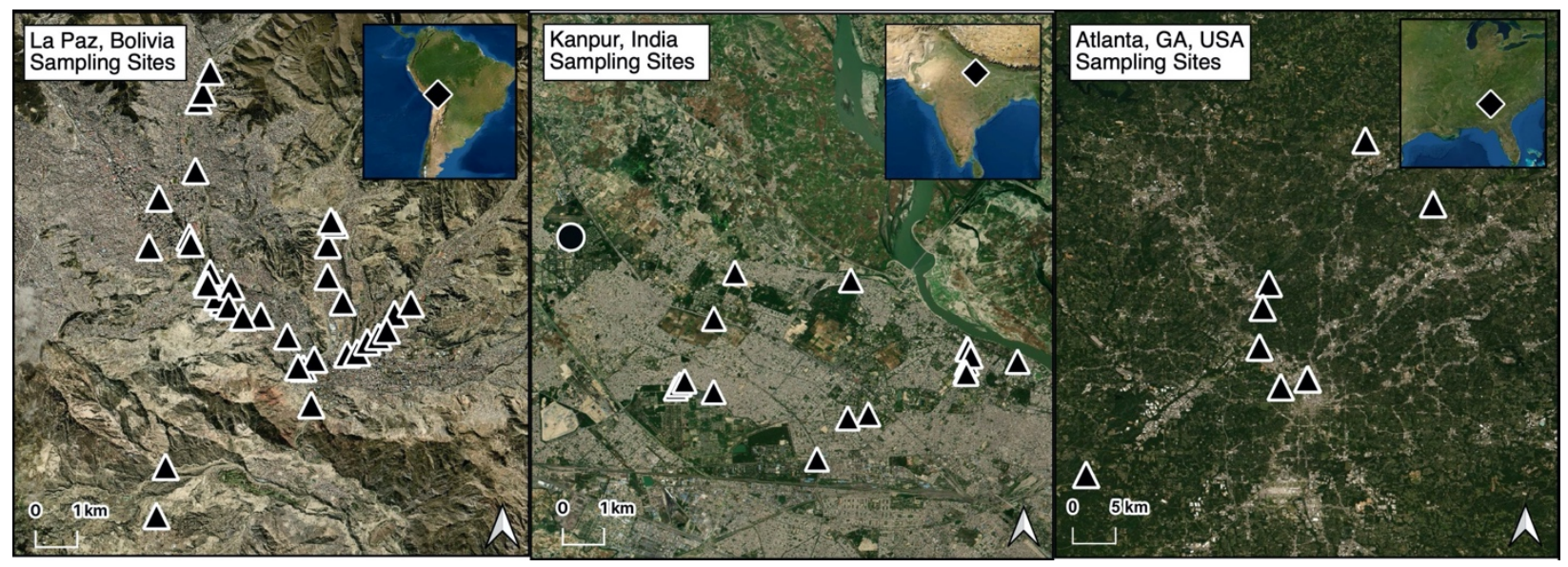

Figure 1. Aerosol sampling sites in La Paz, Bolivia; Kanpur, India; and Atlanta, USA. Sites located $<1$ $\mathrm{km}$ from OWCs are represented by triangles and sites located $>1 \mathrm{~km}$ from OWCs are represented by circles. Control sites outside the city of La Paz not shown.

Bioaerosol sampling, extraction and analysis. We used a combination of high-volume filtration and aerosol impaction in sampling across sites. We used the ACD-200 BobCat Dry Filter Continuous Air Sampler (InnovaPrep, Drexel, MO, USA) with $52 \mathrm{~mm}$ electret filters and a flow rate of $200 \mathrm{~L} / \mathrm{min}$ for downstream molecular analysis post extraction. We applied a single-use wet foam carbon compressed elution kit (InnovaPrep, Drexel, MO, USA) to flush the filter following the manufacturer's instructions, yielding approximately $6 \mathrm{~mL}$ of liquid eluate ${ }^{74}$. We treated the eluate with guanidine thiocyanate-based universal extraction (UNEX; Microbiologics, St. Cloud, MN, USA) lysis buffer in a 1:1 ratio, storing the 
mix in bead tubes for sample transport to the laboratory. As a process control prior to extraction, we spiked the mix with $5 \mathrm{uL}$ of Inforce 3 Bovine Vaccine (Zoetis, Parsippany, NJ) containing bovine respiratory syncytial virus (BRSV) and bovine herpes virus (BoHV). After DNA and RNA lysis, purification, and elution of nucleic acids following the manufacturer's protocol ${ }^{75}$, we stored extracted nucleic acids in 50-75 $\mu \mathrm{L}$ of $10 \mathrm{mM}$ Tris- $1 \mathrm{mM}$ EDTA (pH 8 ) at $-80^{\circ} \mathrm{C}$ until further analysis. In total, we collected 75 high-volume air samples from La Paz (71 collected near OWCs and 4 collected from reference sites $>1 \mathrm{~km}$ from OWCs), 53 high-volume air samples from Kanpur (45 collected near OWCs and 8 collected from one reference site $>1 \mathrm{~km}$ from OWCs), and 15 high-volume air samples in Atlanta.

For all high-volume air samples in Kanpur ( $\mathrm{n}=53)$, we applied $1 \mathrm{~mL}$ of BobCat eluate to Compact Dry-EC (CD-EC) plates (Hardy Diagnostics, Santa Maria, CA, USA) ${ }^{76}$ for culture of total coliform and E. coli. Concurrent with high-volume air sampling in $\operatorname{La~Paz~}(n=31)$ and in Atlanta $(n=15)$, we simultaneously used the Six-Stage Viable Andersen Cascade Impactor (ACI) with plates in six partitioned chambers at a flow rate of approximately $28.5 \mathrm{~L} / \mathrm{min}$ for 1 hour to collect size-resolved bioaerosols in the size range of 0.65 to $>7 \mu \mathrm{m}$ (ACI, Thermo Scientific ${ }^{\mathrm{TM}}$, USA) ${ }^{77}$. We used AquaTest medium (Sisco Research Laboratories PVT. LTD., India) in the ACI to detect E. coli ${ }^{78-80}$. All culture samples were incubated at $37{ }^{\circ} \mathrm{C}$ and counted per the manufacturer's instructions after 18-24 hours for colony forming units (CFUs).

Enteric pathogen screening: multiplex qPCR. As a first step in screening enteric targets, we analyzed high-volume aerosol samples using a custom multiplex qPCR-based TaqMan Array Card (TAC) for the presence or absence of selected targets including enteric viruses (pan-adenovirus, pan-astrovirus, panenterovirus, norovirus GI/II, rotavirus A-C, and sapovirus I/II/IV/V), bacteria (Aeromonas spp., Campylobacter coli, Clostridium difficile, numerous genes of Escherichia coli (SI Table 1), Enterococcus faecalis, Enterococcus faecium, Mycobacterium tuberculosis, Salmonella spp., Shiga toxins, Vibrio cholerae, Yersinia spp.), protozoa (Cryptosporidium parvum, Entamoeba histolytica, Giardia duodenalis), and helminths (Trichuris trichiura, Ascaris lumbricoides) as well as multiple internal controls ${ }^{81}$. We summarize methods previously described below ${ }^{82}$ and further detail them in Supporting Information (SI). Each TAC included eight ports: a no template control (NTC) in the first port, six samples in ports two through 7 and a positive control (PC) in port eight. We used a total reaction mixture of $100 \mu \mathrm{L}$ distributed across each row that included $50 \mathrm{uL}$ of template DNA and $50 \mathrm{uL}$ of qScript XLT 1-step RT-qPCR ToughMix that includes (Quantabio, MA, USA). For the NTC we used molecular water extracted using the same protocol as the samples. For the PC template, we used a single-use aliquot mixture of nucleic acid for each target (gene targets inserted into plasmids) (IDT, Coralville, IA) which were developed using methods previously described ${ }^{83}$. Amplification under $\mathrm{Ct}=40$ was counted as a positive detection given the following criteria were met: (1) there was no amplification in the NTC row except for the internal positive control, (2) the internal positive control column amplified for each row, and (3) there is amplification in the PC row for all targets in all wells. The threshold of amplification was set for each individual assay at the point of inflection and we interpreted samples as positive if there was a clear distinction between the positive and negative amplification curves. A complete description of methods, descriptive statistics, targets, specific classifications of strains and types included in these assays, and their pathogen relevance are detailed in SI Text and SI Table 1. 
Quantitative molecular assays: ddPCR. For density estimation, we conducted absolute quantification of 12 enteric pathogen targets in high-volume aerosol samples via Droplet Digital PCR (ddPCR; QX200 Droplet Digital PCR System, Bio-Rad, Hercules, CA, USA). Targets included nucleic acids associated with selected viruses (adenovirus A-F, pan-enterovirus, norovirus GI, and norovirus GII), bacteria (Campylobacter jejuni, Shigella/EIEC, ST-ETEC, and two targets for Salmonella spp.), and protozoa (Cryptosporidium spp. and Giardia duodenalis) and are detailed in SI Table 2. Targets represent a subset from TAC chosen based on public health relevance in the context of the global enteric disease burden ${ }^{84}$. Although by necessity a sub-set of globally important diarrheagenic pathogens, it includes those responsible for the highest burdens of morbidity and mortality resulting from acute diarrhea ${ }^{85}$ and that have been implicated in large-scale studies of diarrheal etiology ${ }^{84,86-89}$.

Before ddPCR for RNA targets (detailed in SI Table 2), we performed reverse transcription (RT) of RNA to cDNA with a High Capacity cDNA Reverse Transcription Kit with RNase Inhibitor (ThermoFisher Scientific, Waltham, MA). Following the manufacturer's instructions, we added $10 \mu \mathrm{L}$ of nucleic acid extract to $10 \mu \mathrm{L}$ of RT master mix and stored the resulting cDNA at $-80^{\circ} \mathrm{C}$ until further molecular analysis.

During ddPCR, the PCR reaction is partitioned into thousands of individual reaction partitions before amplification and all droplets are analyzed at end-point to enable absolute quantification of target DNA. Unlike qPCR, no standard curve is necessary as targets are quantitatively estimated using a most-probable number technique based on the Poisson distribution and the observed proportion of droplets positive for the target of interest ${ }^{90}$. For probe-based assays, we set reaction mixes to a total volume of $20 \mu \mathrm{L}$ including 0.5 $\mu \mathrm{L}$ each of forward and reverse primer for a final concentration of $900 \mathrm{nM} ; 0.05 \mu \mathrm{L}$ of probe for a final concentration of $250 \mathrm{nM} ; 10 \mu \mathrm{L}$ of $2 \mathrm{X}$ Supermix for Probes (Bio-Rad, Hercules, CA, USA), $5 \mu \mathrm{L}$ of molecular grade water, and $4 \mu \mathrm{L}$ of extract. The only assay not using a probe-based assay was $E$. coli (ybbW) for which we used EvaGreen chemistry in a total reaction volume of $20 \mathrm{uL}$ that included $1 \mu \mathrm{L}$ each of forward and reverse primers for final concentrations of $250 \mathrm{nM} ; 10 \mu \mathrm{L}$ of $2 \mathrm{X}$ EvaGreen Supermix (BioRad, Hercules, CA, USA); $4 \mu \mathrm{L}$ of molecular grade water, and $4 \mu \mathrm{L}$ of extract (Supporting Information). We performed each ddPCR experiment using the Bio-Rad QX200 Droplet Digital PCR System and C1000 Touch Thermal Cycler (Bio-Rad, Hercules, CA, USA). On each ddPCR plate, we included two positive controls, two sample blank controls (extracted elution buffer) and two no-template controls using molecular-grade water to control for contamination via human or other error and to detect false positives. We experimentally determined 95\% limits of detection (LODs) for each assay using a ten-replicate serial dilution series of positive control material and a probit analysis outlined by Stokdyk et. al. ${ }^{91,92}$ The $95 \%$ LOD represents the concentration for which the probability of a single ddPCR reaction being positive is 95\%. Positive control sequences, primers, probes, and experimentally determined 95\% LODs are detailed for each assay in Table S2.

In addition to stratifying by sampling city and season (for La Paz and Kanpur), we further disaggregated data by distance from nearby putative sources. We collected GPS coordinates for each sample site and estimated the linear distance from the nearest OWC or impacted surface water. We use a priori-defined categories of 0-10 m and more than $10 \mathrm{~m}$ from OWCs (or impacted surface waters in Atlanta) and assessed the number of unique target detections per total assays we ran on each sample at each distance category. 
We used a Wilcoxon rank sum test to evaluate whether molecular detections decreased as a function of increasing distance from OWCs. All analyses were completed in RStudio version 1.1.383 and significance was based on $95 \%$ confidence $(\alpha=0.05)$.

\section{RESULTS}

Culturable fecal indicator bacteria in aerosols. Of the 45 air samples we collected in Kanpur near OWCs $(<1 \mathrm{~km})$ and analyzed by culture, $61 \%$ had detectable $E$. coli with an average concentration and $95 \% \mathrm{CI}$ of $1.5 \pm 1.3 \mathrm{CFU} / \mathrm{m}^{3}$ air across positive detections. Across all 45 samples including non-detects, the average concentration of $E$. coli was $0.92 \pm 0.41 \mathrm{CFU} / \mathrm{m}^{3}$ air. All control samples taken $>1 \mathrm{~km}$ away from observed fecal contamination were negative for culturable $E$. coli. In La Paz, adjacent to the Choqueyapu River and its adjoining tributaries, of the 28 air samples in close proximity to uncontained waste $(<1 \mathrm{~km})$ and analyzed for viable coliform, $52 \%$ were positive for $E$. coli with an average concentration and $95 \%$ CI of $11 \pm 3.8$ $\mathrm{CFU} / \mathrm{m}^{3}$ air. Across all 28 samples including non-detects, the average concentration of E. coli was $5.3 \pm 2.1$ $\mathrm{CFU} / \mathrm{m}^{3}$ air. The size distribution capabilities of the ACI revealed that $27 \%$ of culturable $E$. coli were under $2.1 \mu \mathrm{m}$, the size cutoff for fine aerosol particles ${ }^{93}$, indicating potential transport of bioaerosols over a period of hours, with a settling velocity in still air of $0.5 \mathrm{~m} /$ hour for a typical particle with $2 \mu \mathrm{m}$ diameter ${ }^{94}$, indicating high transport potential in air near OWCs (Figure 2). 


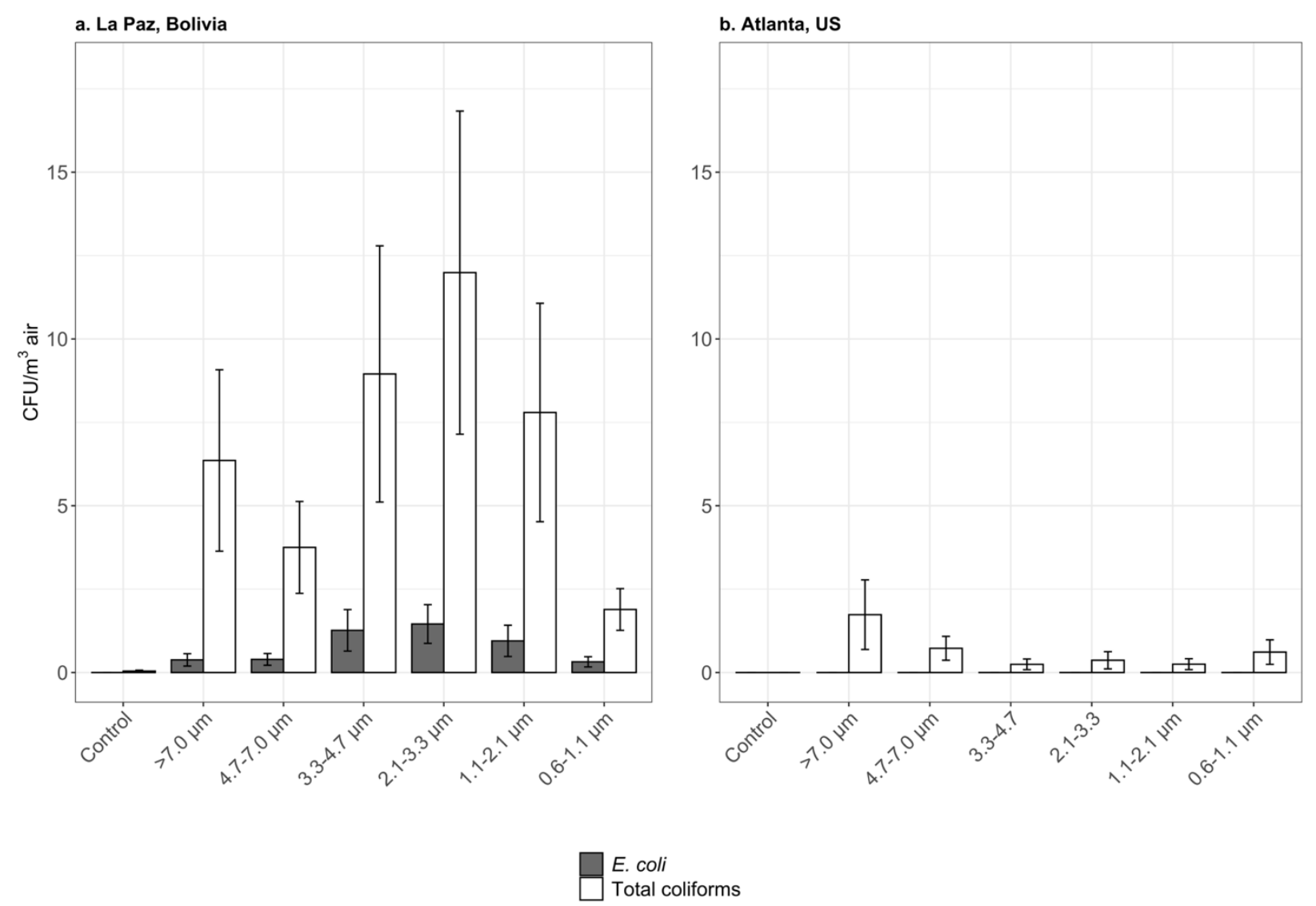

Figure 2. Size distribution of culturable E. coli and total coliform in La Paz and Atlanta. The mean standard error bars show 95\% confidence intervals for densities in each size range. We did not collect ACI samples in Kanpur, so size-resolved E. coli detections by culture are not available for that site.

Screening of enteric microbes in aerosols. We analyzed a subset of 40 high-volume samples from Kanpur, 23 high-volume samples from La Paz, and 13 high-volume samples from Atlanta for the presence and absence of 42 molecular targets including those specific to an a priori-defined list of globally important enteric viruses, bacteria, and protozoa. In La Paz, we detected genes associated with astrovirus and Aeromonas spp. in one of the three control samples. In Kanpur, we detected one each of the following molecular targets in control samples $(\mathrm{n}=8)$ : adenovirus, non-typable rotavirus, Aeromonas spp., $E$. coli/Shigella spp. (ipaH gene), and Yersinia spp. At the control site in Atlanta $(\mathrm{n}=6)$, we detected Aeromonas spp. in one sample.

Positive detections for a priori-defined enteric pathogen-associated gene targets were enriched in samples taken less than $1 \mathrm{~km}$ from known fecal waste flows across all cities. In Kanpur, 53\% of samples ( $\mathrm{n}=13$ ) were positive for at least one target, $28 \%(n=10)$ were positive for at least two targets, and $3 \%(n=4)$ were positive for at least five targets. Among these positive detections were genes associated with two protozoan parasites (Cryptosporidium parvum and Giardia duodenalis), four viruses (pan-astrovirus, pan-enterovirus, norovirus GII, and rotavirus), and five bacteria (Aeromonas spp., Campylobacter coli, pathogenic E. coli (aatA gene), Enterococcus faecium, and Vibrio cholerae). In Bolivia, $76 \%$ of samples ( $\mathrm{n}=16$ ) were positive for at least one target, $62 \%(n=13)$ were positive for at least two targets, and $19 \%(n=4)$ were positive for 
at least five targets. Among these positive detections were five viral targets (adenovirus 40/41, panadenovirus, pan-astrovirus, pan-enterovirus, and norovirus GII), and nine bacterial targets (Aeromonas spp., EAEC, ST-ETEC, LT-ETEC, EIEC/Shigella spp., Enterococcus faecium, Salmonella spp., and Yersinia spp.). In Atlanta, 6 of 13 samples were positive for one target (46\%). Targets detected included one virus (pan-adenovirus) and two bacteria (Aeromonas spp. and Campylobacter coli). There were two Atlanta samples adjacent to the Chattahoochee River positive for adenovirus nucleic acid and one adjacent to Proctor Creek with Campylobacter coli nucleic acid, both above their respective 95\% LODs (SI Table 2). The Chattahoochee commonly experiences levels of fecal indicator bacteria beyond EPA-recommended limits for recreational use, above $235 \mathrm{CFU}$ per $100 \mathrm{~mL}^{70,95,96}$. To compare across cities, we normalized the collection volume to $2000 \mathrm{~m}^{3}$ and calculated the expected number of positives based on measured values. We also highlight the fraction of samples with positive detects that also tested positive for viable E. coli through culture (Figure 3). We detected the highest pathogen diversity in La Paz, with genes specific to two enteric protozoa, nine bacteria, and six viruses among pre-defined targets. In La Paz, we detected multiple genes associated with a diverse array of pathogenic E. coli including EIEC/Shigella, LT and ST-ETEC, and two gene targets for EAEC. In Kanpur, we detected genes associated with two protozoa, five bacteria, and four viruses among pre-defined targets. For all targets, at least one of the positive samples also had culturable E. coli. In Atlanta, we detected gene targets associated with two bacteria and one virus with no co-detection of culturable E. coli.

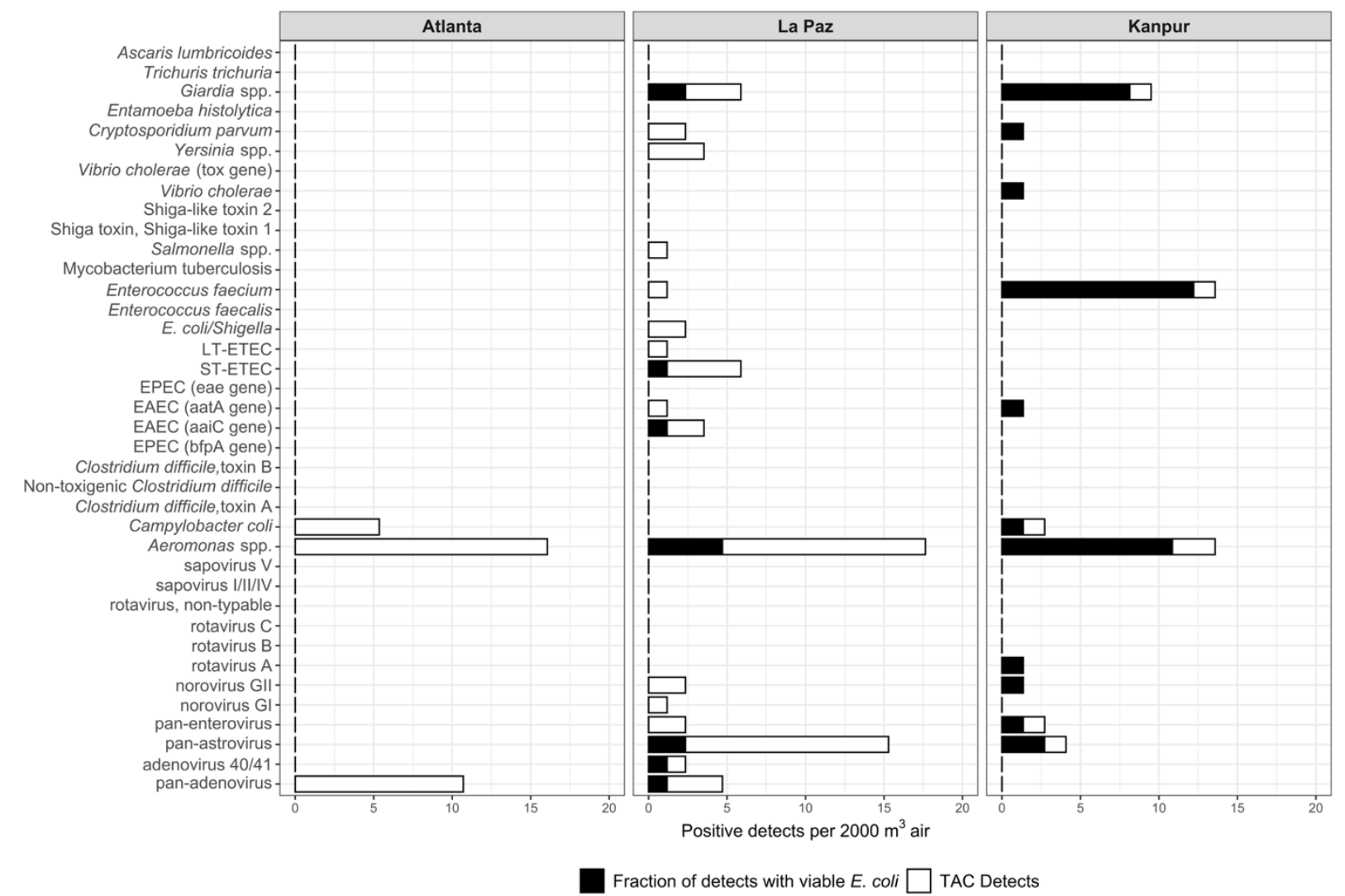

Figure 3. Positive detects via TAC per $2000 \mathrm{~m}^{3}$ air and the fraction of samples positive for culturable $E$. coli. 
Quantitative estimation of enteric microbes in aerosols. We analyzed high-volume samples from the three sites for quantitative estimation of select, pre-defined gene targets associated with globally important enteric pathogens. We censored raw data using the 95\% LOD as a conservative threshold for positivity. In Atlanta, we quantified Shigella spp./EIEC (3 detections). In La Paz, we quantified ST-ETEC (2 detections), Shigella spp./EIEC (16 detections), Campylobacter jejuni (2 detections), Salmonella spp. ttr gene (3 detections), pan-enterovirus (3 detections), adenovirus A-F (1 detection), norovirus GI (3 detections), norovirus GII (3 detections), and Cryptosporidium spp. (3 detections). In Kanpur, we quantified Campylobacter jejuni (1 detection in 53), norovirus GI (33 detections), norovirus GII (1 detection), MS2, (1 detection), and Cryptosporidium spp. (3 detections). Among the detections above the 95\% LOD threshold, target densities ranged from $1.5 \times 10^{1} \mathrm{gc} \mathrm{per}^{3}$ air to $4.7 \times 10^{2} \mathrm{gc} \mathrm{per}^{3}$ air (Figure 4).

We stratified data by distance from OWCs (for Kanpur and La Paz) or impacted urban water sources (Atlanta) (Figure 5). The number of unique targets detected decreased as distance from OWCs increased in La Paz and Kanpur. We observed a downward trend in density for one target in La Paz (EIEC/Shigella spp.) and Kanpur (norovirus GI). Overall, we observed a clear decrease $(p=0.005)$ in the probability of detecting any positive molecular pathogen target (including ddPCR and qPCR detections above LOD) between samples collected within $10 \mathrm{~m}$ and samples collected greater than $10 \mathrm{~m}$ from OWCs in La Paz and Kanpur and impacted urban surface waters in Atlanta. We also observed a decrease in the probability of detecting bacterial, viral, and protozoan molecular pathogen targets $(\mathrm{p}=0.006, \mathrm{p}=0.02$, and $\mathrm{p}=0.009$ respectively) between samples collected within $10 \mathrm{~m}$ and samples collected greater than $10 \mathrm{~m}$ from potential sources. We observed no differences in probability of detection across all targets by seasonality (rainy/dry) in La Paz and Kanpur. 


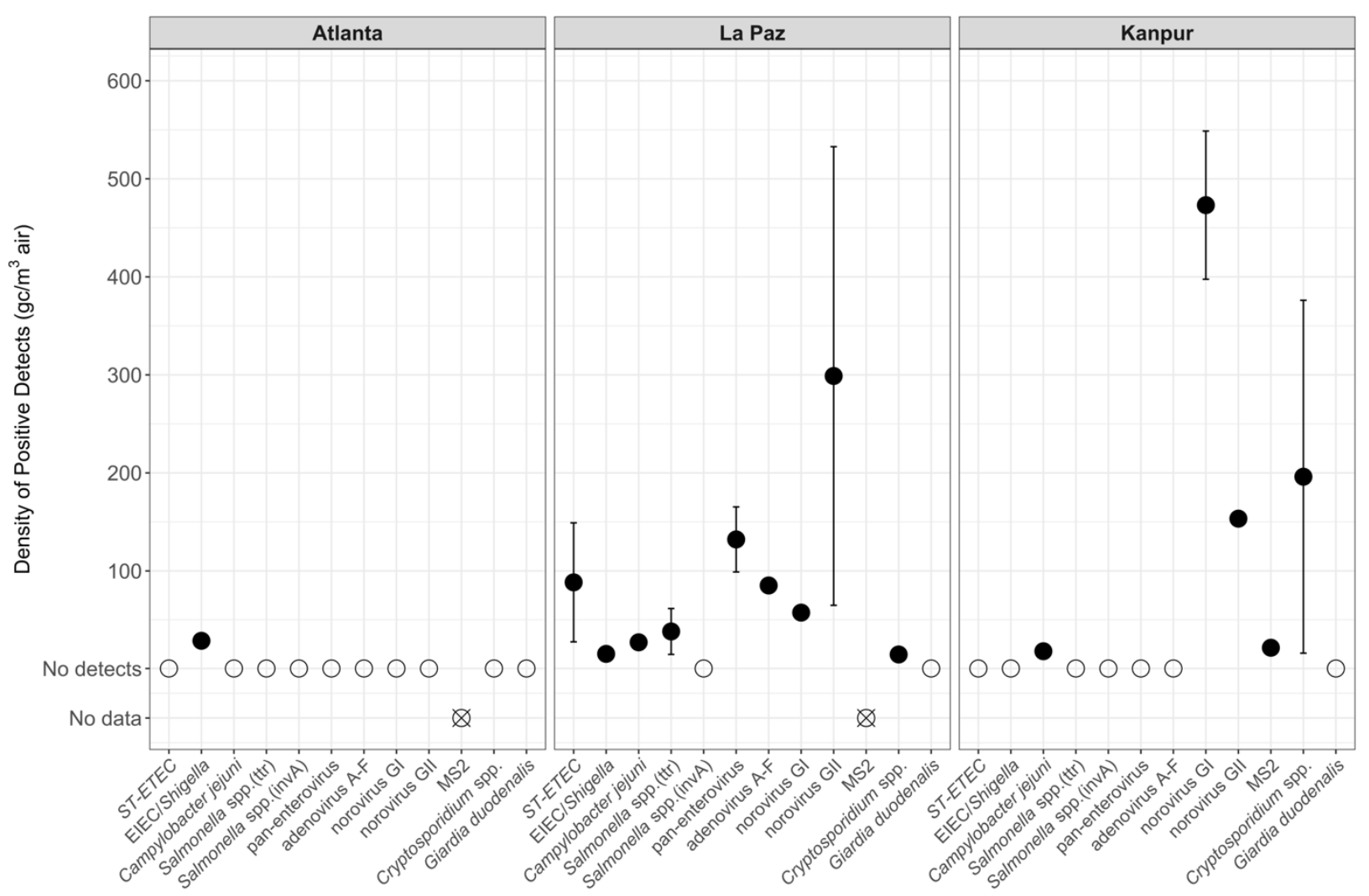

Figure 4. Mean densities of gene targets associated with enteric microbes with mean standard error bars as observed among the distribution of positive detects in gene copies per cubic meter of air. Densities were censored according to the assay-specific 95\% LOD.

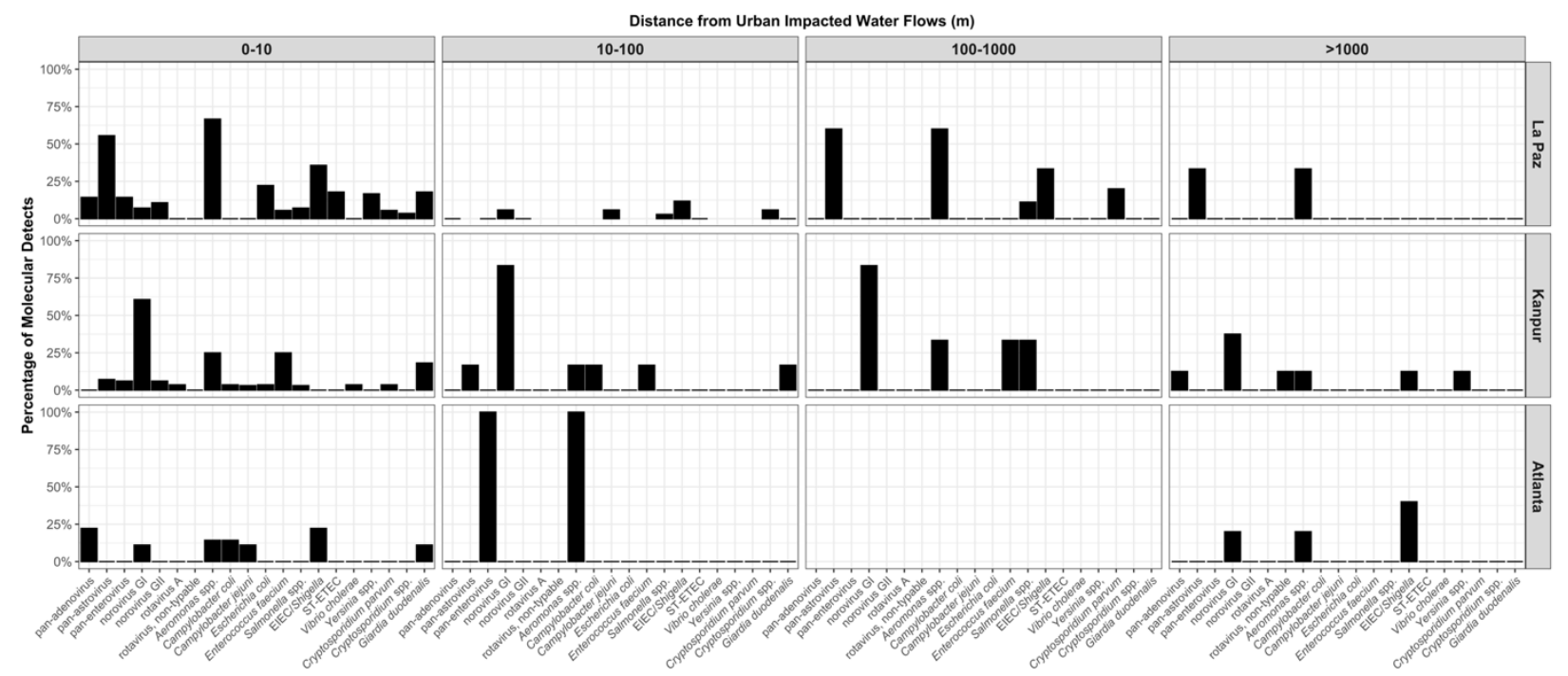

Figure 5. Percentage of positive detects (via TAC or ddPCR) in sample sets for each site versus straightline distance from impacted water flows, where densities were censored according to the assay-specific $95 \%$ LOD. 


\section{DISCUSSION}

Open sewers conveying domestic, institutional, commercial, and industrial effluent are common in cities in LMICs. They may also serve important drainage functions including flooding control. Sewers are often open to the atmosphere because solid waste can clog closed drains, and a lack of adequate solid waste management in some cities makes OWCs a rational approach to removing concentrated waste away from human habitation. They may pose risks, however, both to downstream communities and also people in close proximity to open urban wastewater flows.

Our results suggest that in cities of LMICs with poor sanitation infrastructure and the presence of concentrated, uncontained fecal waste streams in open sewers, genes specific to enteric microbes, many pathogenic, are present in aerosols and may disseminate in the environment. Overall, detection of fecal microbes in aerosols was higher than we expected at each of our study sites, suggesting this phenomenon may be common in similar settings. The diversity and density of enteric microbes was enriched in La Paz and Kanpur compared with reference sampling in Atlanta and was greater near open wastewater canals and impacted surface waters. The co-detection of culturable E. coli in a high percentage of samples in La Paz and in Kanpur suggests, indirectly, that some pathogens detected could have been viable at the point of sampling. We observed no culturable E. coli in aerosols sampling in Atlanta. The health risk implications of the presence of aerosolized enteric microbes in these settings are unknown but merit further study.

Our study included a range of pathogen targets of global public health relevance, many of which have not been previously detected in urban outdoor aerosols where infection risk is a clear possibility due to the proximity of concentrated waste and high population density. In La Paz, we quantified heat-stable enterotoxigenic E. coli (ST-ETEC) in two aerosol samples at densities of $28 \mathrm{gc} / \mathrm{m}^{3}$ air and $150 \mathrm{gc} / \mathrm{m}^{3}$ air. ETEC was responsible for 50,000 deaths worldwide in $2016^{97}$ but has not been previously quantified in extramural aerosols in cities where transmission is endemic. Also in La Paz, we report the first quantitative estimate of enteroinvasive $E$. coli or Shigella (ipaH gene, $\mathrm{n}=16$ ) in a similar setting at densities ranging from $1.8 \mathrm{gc} / \mathrm{m}^{3}$ air to $53 \mathrm{gc} / \mathrm{m}^{3}$ air. We detected and quantified other enteric bacteria not previously observed in extramural urban aerosols such as Campylobacter coli and Salmonella spp., though they have been previously quantified in air near concentrated animal feeding operations ${ }^{98,99}$.

We observed comparable prevalence of Aeromonas spp. associated nucleic acids in Atlanta, La Paz, and Kanpur with 8, 9, and 7 positive detections per $1000 \mathrm{~m}^{3}$ air at each site respectively. Aeromonas spp. have been consistently detected in environmental media in a variety of settings ${ }^{110}$. Although some aeromonads are important human pathogens, in 2016 Aeromonas spp. were responsible for only 1\% of total diarrheal deaths and only 19 of 36 subtypes are known to be pathogenic. ${ }^{97,111}$

Among viral detects in Kanpur and in La Paz, norovirus GI and GII may be most risk-relevant. We detected norovirus GI and GII at the highest average density across all targets in Kanpur aerosol samples (320 $\mathrm{gc} / \mathrm{m}^{3}$ air and $150 \mathrm{gc} / \mathrm{m}^{3}$ air respectively). In La Paz, we detected norovirus GII at the highest average density across all targets $\left(13 \mathrm{gc} / \mathrm{m}^{3}\right.$ air $)$ and norovirus GI at a mean of $2.4 \mathrm{gc} / \mathrm{m}^{3}$ air. Norovirus is relatively resistant to inactivation in environmental media ${ }^{100}$, may persist on environmental surfaces for up to two weeks ${ }^{101}$, has been shown to survive in aerosols ${ }^{102-106}$, and has an estimated relatively low median infectious dose 
between 18 and $10^{3}$ virus particles ${ }^{107}$. It is among the most widely prevalent viral enteric pathogens, globally, with an estimated 33,000 cases and 20,000 deaths per year ${ }^{97,108,109}$.

We are aware of only one previous study reporting detection of enteric protozoan parasites in air samples, from rural Mexico, by microscopy; the study reported 8 of 12 samples positive for Cryptosporidium and 10 of 12 samples positive for Giardia, possibly via aerosolization of soil ${ }^{112}$. By comparison we detected Giardia duodenalis via qPCR in $22 \%$ of samples in Bolivia and $18 \%$ of samples in India, with 3 and 5 positive detections per $1000 \mathrm{~m}_{\text {air }}^{3}$ at each site respectively. Cryptosporidium was present in $9 \%$ and $3 \%$ of samples in Bolivia and India respectively with 1 positive detection per $1000 \mathrm{~m}_{\text {air }}^{3}$ at both sites. We quantified Cryptosporidium spp. in aerosol samples via ddPCR in La Paz $(n=3)$ and in India $(n=2)$ at average densities ranging from $9.3 \mathrm{gc} / \mathrm{m}^{3}$ air to $560 \mathrm{gc} / \mathrm{m}^{3}$ air, the second time Cryptosporidium has been reported in an aerosol and the first quantitative estimate.

A small number of previous studies have identified the likely presence of aerosolized fecal material and potential for pathogen transmission in bioaerosols in similar settings. Our previous studies in La Paz and Kanpur reported detection of culturable Enterobacteriaceae and E. coli in ambient urban air that was hypothesized to also originate from $\mathrm{OWCs}^{113-115}$. A study in Malawi measured the presence of enteric microbes in ambient air (enterotoxigenic E. coli) before, during, and after pit latrine emptying, confirming that these microbes increased in nearby aerosols during pit latrine emptying events ${ }^{58}$. In 22 samples of outdoor aerosols collected in Mumbai, 28 species of culturable bacteria were identified including several opportunistic pathogens: Staphylococcus spp., Serratia plymuthica, Serratia haemolyticus, and Enterobacter aerogenes ${ }^{54}$. Bacterial bioaerosols including opportunistic pathogens have similarly been identified using 16S rDNA sequencing near composting facilities in India ${ }^{50}$. Staphylococcus aureus and other opportunistic pathogens have been identified in urban environments in the Philippines ${ }^{59}$. A larger study from Beijing, China identified many of the same genera in addition to 16 species of Pseudomonas (some potential opportunistic pathogens) and the possibly fecal-associated genera Enterococcus, Escherichia, Vibrio, and Yersinia ${ }^{53}$. Our results further support previous limited evidence that fecal microbes can be present in urban aerosols. Our quantitative estimates of specific pathogens are an initial step toward further work in understanding the implications of the presence of these microbes in air, including fate and transport modeling and risk assessment.

The concurrent detection of culturable E. coli in many samples from La Paz and Kanpur suggests that some of these important pathogenic bacteria (including pathogenic E. coli), viruses, and protozoa we detected may have been viable at the point of sampling. As a commonly used fecal indicator bacterium, E. coli suggests - though does not conclusively demonstrate - the presence of aerosolized fecal material in samples $^{116}$. Culturable E. coli also may indicate recently aerosolized material, since vegetative bacteria are not persistent in the aerosolized state and may be quickly inactivated if ideal conditions are not met. ${ }^{102}$ Other sanitation-related pathogens, such as those showing greater persistence in the environment (e.g., Cryptosporidium oocysts) may persist for longer periods in environmental media ${ }^{117}$ than co-occurring vegetative bacteria ${ }^{118}$, suggesting that culturable $E$. coli may conservatively represent the potential viability of other enteric pathogens. More work on the comparative survival of pathogens in extramural aerosols is 
needed, however. Such studies are challenging to conduct, because the methods for capturing aerosolized enteric pathogens at low densities are not conducive to preserving viability ${ }^{119-121}$.

There is some epidemiological evidence that proximity to concentrated fecal waste streams in urban areas can be related to enteric infection risk. Contreras et al. ${ }^{122}$, assessing the spatial relationship between household proximity to fecal contaminated surface water canals used for crop irrigation and diarrheal disease in children in multiple municipalities in the Mezquital Valley in Mexico, determined that compared to children under 5 living within $10 \mathrm{~m}$ from a canal, children living $100 \mathrm{~m}$ from a canal had $45 \%$ lower odds of diarrhea and children living $1000 \mathrm{~m}$ from a canal had $70 \%$ lower odds of diarrhea. They further estimated that $24 \%$ of all diarrheal cases in the study and $50 \%$ of all cases within $100 \mathrm{~m}$ from a canal were attributable to canal exposure. The authors posited aerosolization of pathogens from canals as a potential pathway of exposure in this setting.

This study had a number of important limitations that deserve consideration. First, the viability of enteric pathogens detected by molecular methods in aerosols cannot be assumed, even with co-culture of fecal indicator bacteria. Although E. coli viability in samples may indirectly indicate potential viability of other microbes present in bioaerosols, and vegetative bacteria may represent a conservative proxy since they have been shown to survive relatively poorly in aerosols ${ }^{117,123}$, we did not measure viability of other microbes directly. The methods we used for high-volume samples present high pressure and desiccating conditions that may reduce viability of microbes captured on the filter ${ }^{124}$, and may also have resulted in an underestimation of culturable total coliforms and E. coli in Kanpur; in contrast, the ACI used in Bolivia and Atlanta is suitable for coliform survival and growth since bioaerosols are impacted at a lower flow rate onto nutrient-rich, semi-solid agar media. High-volume aerosol sampling generally presents conditions that are known to limit recovery of viable microbes ${ }^{125}$. Capture methods that preserve viability, such as impingement ${ }^{56}$ and water-vapor condensation ${ }^{126}$ typically operate at relatively low flow rates (8 - 13 liters per minute), requiring extended periods to capture targets present at low densities. We further acknowledge that pathogen-specific nucleic acids in aerosols could be attributable to either viable or inactivated microbes, or may exist as extracellular genetic material in the environment. Second, while our data suggest concentrated fecal waste streams as potential sources of aerosolized sanitation-related microbes in nearby air samples, and we observed a trend of decreasing density with increasing distance from fecal waste streams, we cannot definitively conclude that enteric microbes in aerosols derive from these sources. Cities with poor sanitation infrastructure typically have many contaminated sites, including OWCs and drains but also latrine pits ${ }^{58,127}$, composting sites $^{50}$, or solid waste ${ }^{128,129}$. Animals and animal waste may be common and could be aerosolized. Further work is needed on methods for source-tracking of bioaerosols, including via sequencing approaches. Third, our molecular results are likely conservative representations of target densities in ambient air of the sampling locations based on laboratory experiments with the high-volume sampler that reveal recovery efficiencies of $1 \mu \mathrm{m}$ particles ranging from $73 \%$ in conditions most similar to those of our study ${ }^{125}$ to $101 \%$ under controlled laboratory conditions ${ }^{130}$. Finally, this study included a limited sample size across the wide range of enteric pathogen targets we sought, constraining statistical power for assessment of risk factors for pathogen detection across sites. Further studies of specific pathogen transport under specific controlled conditions are needed to fully describe mechanisms of aerosolization, transport, deposition, viability and persistence in aerosols, and risk of exposure to humans. 
We highlight aerosol transport as playing a potentially important and understudied role in the spread of microbes originating in fecal wastes in outdoor environments with uncertain implications for human exposure, infection, and disease transmission. Fecal-oral transmission of enteric pathogens is often summarized in the so-called F-diagram, describing key media that serve as direct and indirect sources of enteric pathogen spread: water, soil, hands, fomites and surfaces, food, and flies ${ }^{5,131,132}$. Aerosols should be added to this conceptual framework. Aerosols may allow for transport of enteric pathogens between and among media, contributing to the spread of fecal contamination and associated microbes, resulting in potential for greater exposure via contact, inhalation, or ingestion either directly or indirectly following deposition on a surface, food, water or other subsequent exposure pathway ${ }^{24,122}$. In many settings, multiple relevant pathways of exposure may exist ${ }^{133}$, and aerosols may be one more whose risk relevance remains uncharacterized but cannot be excluded from consideration. A complete accounting of enteric pathogen transport is required to design intervention strategies with the potential to control exposures. In high-burden settings such as rapidly densifying cities in LMICs with poor sanitation, enteric pathogen transport via aerosols near concentrated fecal waste flows merits further investigation. Direct measures of pathogen viability and persistence in aerosols, exposure modeling, quantitative microbial risk assessment, and epidemiological studies would be useful next steps in further characterizing the public health relevance of this phenomenon.

\section{ACKNOWLEDGEMENTS}

This material is based upon work supported by the National Science Foundation under grant number 1653226. Many thanks to colleagues at IIT-Kanpur including Hari Shankar, Harish Vishwakarma, Shivshankar Mishraa and numerous others who helped with instrumentation and shared their laboratory space. We further acknowledge the kind people who shared their homes and their tea with us as we sampled in the community. Thanks to all colleagues at Universidad Católica Boliviana and Universidad Mayor de San Andrés, including undergraduate assistants.

\section{REFERENCES}

(1) WHO; UNICEF. Progress on Household Drinking Water, Sanitation and Hygiene 2000-2017. Special Focus on Inequalities; 2019.

(2) Peal, A.; Evans, B.; Blackett, I.; Hawkins, P.; Heymans, C. Fecal Sludge Management: A Comparative Analysis of 12 Cities. J. Water, Sanit. Hyg. Dev. 2014, 4 (4), 563.

(3) Berendes, D. M.; Sumner, T. A.; Brown, J. M. Safely Managed Sanitation for All Means Fecal Sludge Management for at Least 1.8 Billion People in Low and Middle Income Countries. Environ. Sci. Technol. 2017, 51 (5), 3074-3083.

(4) Rietveld, L. C.; Siri, J. G.; Chakravarty, I.; Arsénio, A. M.; Biswas, R.; Chatterjee, A. Improving Health in Cities through Systems Approaches for Urban Water Management. Environ. Heal. A Glob. Access Sci. Source 2016, 15 (Suppl 1).

(5) Wagner, E. G.; Lanoix, J. N. Excreta Disposal for Rural Areas and Small Communities; World Health Organization, 1958.

(6) Walls, P. L. L.; Bird, J. C.; Bourouiba, L. Moving with Bubbles: A Review of the Interactions between Bubbles and the Microorganisms That Surround Them. Integr. Comp. Biol. 2014, 54 (6), 
1014-1025.

(7) Bourouiba, L.; Bush, J. W. M. Drops and Bubbles in the Environment. Handb. Environ. Fluid Dyn. Vol. One Overv. Fundam. 2012, 427-439.

(8) Poulain, S.; Villermaux, E.; Bourouiba, L. Ageing and Burst of Surface Bubbles. J. Fluid Mech. 2018, 851, 636-671.

(9) Schmale, D. G.; Ross, S. D. Highways in the Sky: Scales of Atmospheric Transport of Plant Pathogens. Annu. Rev. Phytopathol. 2015, 53 (1), 591-611.

(10) Kim, S.; Park, H.; Gruszewski, H. A.; Schmale, D. G.; Jung, S. Vortex-Induced Dispersal of a Plant Pathogen by Raindrop Impact. Proc. Natl. Acad. Sci. U. S. A. 2019, 116 (11), 4917-4922.

(11) Dueker, M. E. Connecting Water Quality With Air Quality Through Microbial Aerosols. 2012.

(12) Inizan, M. Turbulence-Particle Interactions on Surfaces. Massachusetts Inst. Technol. 2018, 110.

(13) Alsved, M.; Bourouiba, L.; Duchaine, C.; Löndahl, J.; Marr, L. C.; Parker, S. T.; Prussin, A. J.; Thomas, R. J. Natural Sources and Experimental Generation of Bioaerosols: Challenges and Perspectives. Aerosol Sci. Technol. 2020, 54 (5), 547-571.

(14) Griffin, D. W. Atmospheric Movement of Microorganisms in Clouds of Desert Dust and Implications for Human Health. Clin. Microbiol. Rev. 2007, 20 (3), 459-477.

(15) Joung, Y. S.; Ge, Z.; Buie, C. R. Bioaerosol Generation by Raindrops on Soil. Nat. Commun. 2017, $8,1-10$.

(16) Rathnayake, C. M.; Metwali, N.; Jayarathne, T.; Kettler, J.; Huang, Y.; Thorne, P. S.; O'Shaughnessy, P. T.; Stone, E. A. Influence of Rain on the Abundance of Bioaerosols in Fine and Coarse Particles. Atmos. Chem. Phys. 2017, 17 (3), 2459-2475.

(17) Joung, Y. S.; Buie, C. R. Aerosol Generation by Raindrop Impact on Soil. Nat. Commun. 2015, 6 (May 2014), 1-9.

(18) Heo, K. J.; Kim, H. B.; Lee, B. U. Concentration of Environmental Fungal and Bacterial Bioaerosols during the Monsoon Season. J. Aerosol Sci. 2014, 77, 31-37.

(19) Brodie, E. L.; DeSantis, T. Z.; Parker, J. P. M.; Zubietta, I. X.; Piceno, Y. M.; Andersen, G. L. Urban Aerosols Harbor Diverse and Dynamic Bacterial Populations. Proc. Natl. Acad. Sci. 2007, 104 (1), 299-304.

(20) Rajput, P.; Anjum, M. H.; Gupta, T. One Year Record of Bioaerosols and Particles Concentration in Indo-Gangetic Plain: Implications of Biomass Burning Emissions to High-Level of Endotoxin Exposure. Environ. Pollut. 2017, 224, 98-106.

(21) Rathnayake, C. M. Bioaerosols in the Midwestern United States: Spatio-Temporal Variations, Meteorological Impacts and Contributions to Particulate Matter. 2016.

(22) Dueker, M. E.; O’Mullan, G. D. Aeration Remediation of a Polluted Waterway Increases NearSurface Coarse and Culturable Microbial Aerosols. Sci. Total Environ. 2014, 478, 184-189.

(23) Montero, A.; Dueker, M. E.; O’Mullan, G. D. Culturable Bioaerosols along an Urban Waterfront Are Primarily Associated with Coarse Particles. PeerJ 2016, 2016 (12), 1-18.

(24) de Man, H.; Heederik, D. D. J.; Leenen, E. J. T. M.; de Roda Husman, A. M.; Spithoven, J. J. G.; van Knapen, F. Human Exposure to Endotoxins and Fecal Indicators Originating from Water Features. Water Res. 2014, 51, 198-205.

(25) Gotkowska-Plachta, A.; Filipkowska, Z.; Korzeniewska, E.; Janczukowicz, W.; Dixon, B.; Golas, I.; Szwalgin, D. Airborne Microorganisms Emitted from Wastewater Treatment Plant Treating 
Domestic Wastewater and Meat Processing Industry Wastes. CLEAN-SOIL AIR WATER 2013, 41 (5), 429-436.

(26) Yang, K.; Li, L.; Wang, Y.; Xue, S.; Han, Y.; Liu, J. Airborne Bacteria in a Wastewater Treatment Plant: Emission Characterization, Source Analysis and Health Risk Assessment. Water Res. 2018.

(27) Fannin, K. F.; Vana, S. C.; Jakubowski, W. Effect of an Activated Sludge Wastewater Treatment Plant on Ambient Air Densities of Aerosols Containing Bacteria and Viruses. 1985, 49 (5), 11911196.

(28) Benami, M.; Busgang, A.; Gillor, O.; Gross, A. Quantification and Risks Associated with Bacterial Aerosols near Domestic Greywater-Treatment Systems. Sci. Total Environ. 2016, 562, 344-352.

(29) Sawyer, B.; Rao, K. C.; O’Brien, P.; Elenbogen, G.; Zenz, D. R.; Lue-Hing, C. Changes in Bacterial Aerosols with Height above Aeration Tanks. Journal of Environmental Engineering. 1996.

(30) Lin, K.; Marr, L. C. Aerosolization of Ebola Virus Surrogates in Wastewater Systems. Environ. Sci. Technol. 2017, 51 (5), 2669-2675.

(31) Sánchez-Monedero, M. A.; Aguilar, M. I.; Fenoll, R.; Roig, A. Effect of the Aeration System on the Levels of Airborne Microorganisms Generated at Wastewater Treatment Plants. Water Res. 2008, 42 (14), 3739-3744.

(32) Gangamma, S.; Patil, R. S.; Mukherji, S. Characterization and Proinflammatory Response of Airborne Biological Particles from Wastewater Treatment Plants. Environ. Sci. Technol. 2011, 45 (8), 3282-3287.

(33) Lue-Hing, C.; Zenz, D. R.; Sedita, S. J. Environmental Impact of the Microbial Aerosol Emissions From Wastewater Treatment Plants. Heal. (San Fr. 1982, 289-309.

(34) Cronholm, L. S. Potential Health Hazards from Microbial Aerosols in Densely Populated Urban Regions Potential Health Hazards from Microbial Aerosols in Densely Populated Urban Regions. 1980, 39 (1), 6-12.

(35) Heinonen-Tanski, H.; Reponen, T.; Koivunen, J. Airborne Enteric Coliphages and Bacteria in Sewage Treatment Plants. Water Res. 2009, 43 (9), 2558-2566.

(36) Paez-Rubio, T.; Viau, E.; Romero-Hernandez, S.; Peccia, J. Source Bioaerosol Concentration and RRNA Gene-Based Identification of Microorganisms Aerosolized at a Flood Irrigation Wastewater Reuse Site. Appl. Environ. Microbiol. 2005, 71 (2), 804-810.

(37) Sawyer, B.; Elenbogen, G.; Rao, K. C.; O’Brien, P.; Zenz, D. R.; Lue-Hing, C. Bacterial Aerosol Emission Rates from Municipal Wastewater Aeration Tanks. Appl. Environ. Microbiol. 1993, 59 (10), 3183-3186.

(38) Dungan, R. S. Estimation of Infectious Risks in Residential Populations Exposed to Airborne Pathogens during Center Pivot Irrigation of Dairy Wastewaters. Environ. Sci. Technol. 2014, 48 (9), 5033-5042.

(39) Tanner, B. D.; Brooks, J. P.; Gerba, C. P.; Haas, C. N.; Josephson, K. L.; Pepper, I. L. Estimated Occupational Risk from Bioaerosols Generated during Land Application of Class B Biosolids. $J$. Environ. Qual. 2008, 37 (6), 2311.

(40) Viau, E.; Bibby, K.; Paez-Rubio, T.; Peccia, J. Toward a Consensus View on the Infectious Risks Associated with Land Application of Sewage Sludge. Environ. Sci. Technol. 2011, 45 (13), 54595469.

(41) Paez-Rubio, T.; Ramarui, A.; Sommer, J.; Xin, H.; Anderson, J.; Peccia, J. Emission Rates and 
Characterization of Aerosols Produced during the Spreading of Dewatered Class B Biosolids. Environ. Sci. Technol. 2007, 41 (10), 3537-3544.

(42) Pillai, S. D. Bioaerosols from Land-Applied Biosolids: Issues and Needs. Water Environ. Res. 2007, 79 (3), 270-278.

(43) Brooks, J. P.; Tanner, B. D.; Josephson, K. L.; Gerba, C. P.; Haas, C. N.; Pepper, I. L. A National Study on the Residential Impact of Biological Aerosols from the Land Application of Biosolids. $J$. Appl. Microbiol. 2005, 99 (2), 310-322.

(44) Brooks, J. P.; Gerba, C. P.; Pepper, I. L. Diversity of Aerosolized Bacteria during Land Application of Biosolids. J. Appl. Microbiol. 2007, 103 (5), 1779-1790.

(45) Brooks, J. P.; Tanner, B. D.; Gerba, C. P.; Haas, C. N.; Pepper, I. L. Estimation of Bioaerosol Risk of Infection to Residents Adjacent to a Land Applied Biosolids Site Using an Empirically Derived Transport Model. J. Appl. Microbiol. 2005, 98 (2), 397-405.

(46) Baertsch, C.; Paez-Rubio, T.; Viau, E.; Peccia, J. Source Tracking Aerosols Released from LandApplied Class B Biosolids during High-Wind Events. Appl. Environ. Microbiol. 2007, 73 (14), 4522-4531.

(47) Shuval, H. I.; Guttman-Bass, N.; Applebaum, J.; Fattal, B. Aerosolized Enteric Bacteria and Viruses Generated by Spray Irrigation of Wastewater. Water Sci. Technol. 1989, 21 (3), 131-135.

(48) Teltsch, B.; Katzenelson, E. Airborne Enteric Bacteria and Viruses from Spray Irrigation with Wastewater. Appl. Environ. Microbiol. 1978, 35 (2), 290-296.

(49) Pankhurst, L. J.; Akeel, U.; Hewson, C.; Maduka, I.; Pham, P.; Saragossi, J.; Taylor, J.; Lai, K. M. Understanding and Mitigating the Challenge of Bioaerosol Emissions from Urban Community Composting. Atmos. Environ. 2011, 45 (1), 85-93.

(50) Pahari, A. K.; Dasgupta, D.; Patil, R. S.; Mukherji, S. Emission of Bacterial Bioaerosols from a Composting Facility in Maharashtra, India. Waste Manag. 2016, 53, 22-31.

(51) Gao, X.; Shao, M.; Luo, Y.; Dong, Y.; Ouyang, F.; Dong, W.; Li, J. Airborne Bacterial Contaminations in Typical Chinese Wet Market with Live Poultry Trade. Sci. Total Environ. 2016, $572,681-687$.

(52) Cronholm, L. S. Potential Health Hazards from Microbial Aerosols in Densely Populated Urban Regions. 1980, 39 (1), 6-12.

(53) Fang, Z.; Ouyang, Z.; Zheng, H.; Wang, X.; Hu, L. Culturable Airborne Bacteria in Outdoor Environments in Beijing, China. Microb. Ecol. 2007, 54 (3), 487-496.

(54) Gangamma, S. Characteristics of Airborne Bacteria in Mumbai Urban Environment. Sci. Total Environ. 2014, 488-489 (1), 70-74.

(55) Green, C. F.; Gibbs, S. G.; Tarwater, P. M.; Mota, L. C.; Scarpino, P. V. Bacterial Plume Emanating from the Air Surrounding Swine Confinement Operations. J. Occup. Environ. Hyg. 2006, 3 (1), 915.

(56) Ko, G.; Simmons III, O. D.; Likirdopulos, C. A.; Worley-Davis, L.; Williams, M.; Sobsey, M. D. Investigation of Bioaerosols Released from Swine Farms Using Conventional and Alternative Waste Treatment and Management Technologies. Environ. Sci. Technol. 2008, 42 (23), 8849-8857.

(57) Pillai, S. D.; Ricke, S. C. Bioaerosols from Municipal and Animal Wastes: Background and Contemporary Issues. Can. J. Microbiol. 2002, 48 (8), 681-696.

(58) Farling, S.; Rogers, T.; Knee, J. S.; Tilley, E. A.; Brown, J.; Deshusses, M. A. Bioaerosol Emissions 
Associated with Pit Latrine Emptying Operations. Sci. Total Environ. 2019, 648, 1082-1086.

Rendon, R. V. C.; Garcia, B. C. B.; Vital, P. G. Assessment of Airborne Bacteria in Selected Occupational Environments in Quezon City, Philippines. Arch. Environ. Occup. Heal. 2017, 72 (3), $178-183$.

(60) Kumar, P. CENSUS OF INDIA 2011 Series 10 Part XII-A District Census Handbook.

(61) Singh, R. P. Effect of Wastewater Disposal and Extent of Industrial Pollution in and around Kanpur, Uttar Pradesh, India. Bull. Eng. Geol. Environ. 2001, 60 (1), 31-35.

(62) Zia, H.; Devadas, V. Urban Solid Waste Management in Kanpur: Opportunities and Perspectives. Habitat Int. 2008, 32 (1), 58-73.

(63) Poma, V.; Mamani, N.; Iñiguez, V. Impact of Urban Contamination of the La Paz River Basin on Thermotolerant Coliform Density and Occurrence of Multiple Antibiotic Resistant Enteric Pathogens in River Water, Irrigated Soil and Fresh Vegetables. Springerplus 2016, 5 (1).

(64) Alarcon Calderon, V. J. A Water Quality Model of the Choqueyapu River, La Paz, Bolivia. 1996, $1-24$.

(65) INE. Bolivia cuenta con más de 11 millones de habitantes a 2018 https://www.ine.gob.bo/index.php/notas-de-prensa-y-monitoreo/item/3170-bolivia-cuenta-conmas-de-11-millones-de-habitantes-a-2018 (accessed Jan 22, 2020).

(66) Ohno, A; Marui, A; Castro, ES; Reyes, AA; Elio-Calvo, D; Kasitani, H; Ishii, Y; Yamaguchi, K. Enteropathogenic Bacteria in the La Paz River of Bolivia. Am. J. Trop. Med. Hyg. 1997, 57 (4), 438-44.

(67) Guzman-Otazo, J.; Gonzales-Siles, L.; Poma, V.; Bengtsson-Palme, J.; Thorell, K.; Flach, C.-F.; Iñiguez, V.; Sjöling, Å. Diarrheal Bacterial Pathogens and Multi-Resistant Enterobacteria in the Choqueyapu River in La Paz, Bolivia. PLoS One 2019, 14 (1), e0210735.

(68) Hollabaugh, C. L.; Harris, R. R.; Jackson, J. A. The Role of Urban Runoff, Sewage Discharge, and Chicken Manure on the Water Quality of the Chattahoochee River. Environ. Geosci. 2004, 11 (1), $16-27$.

(69) Aulenbach, B. T.; McKee, A. M. . Monitoring and Real-Time Modeling of Escherichia Coli Bacteria for the Chattahoochee River, Chattahoochee River National Recreation Area , Georgia , 2000 2019; Georgia, 2020.

(70) McKee, B. A.; Molina, M.; Cyterski, M.; Couch, A. Microbial Source Tracking (MST) in Chattahoochee River National Recreation Area: Seasonal and Precipitation Trends in MST Marker Concentrations, and Associations with E. Coli Levels, Pathogenic Marker Presence, and Land Use. Water Res. 2020, 171, 115435.

(71) Rose, S. The Effects of Urbanization on the Hydrochemistry of Base Flow within the Chattahoochee River Basin (Georgia, USA). J. Hydrol. 2007, 341 (1-2), $42-54$.

(72) Schoonover, J. E.; Lockaby, B. G. Land Cover Impacts on Stream Nutrients and Fecal Coliform in the Lower Piedmont of West Georgia. J. Hydrol. 2006, 331 (3-4), 371-382.

(73) United States Census Bureau, P. D. Annual Estimates of the Resident Population for Incorporated Places of 50,000 or More, Ranked by July 1, 2019 Population: April 1, 2010 to July 1, 2019.

(74) AlburtyLab. Summary Technical Report InnovaPrep LLC Dry Filter Collection / Wet Elution Aspiration and Recovery Efficiency Testing For: Andrew Page, President \& CTO.

(75) Hill, V.; Narayanan, J.; Gallen, R.; Ferdinand, K.; Cromeans, T.; Vinjé, J. Development of a Nucleic 
Acid Extraction Procedure for Simultaneous Recovery of DNA and RNA from Diverse Microbes in Water. Pathogens 2015, 4 (2), 335-354.

(76) Kodaka, H.; Mizuochi, S.; Teramura, H.; Nirazuka, T. Comparison of the Compact Dry EC with the Most Probably Number Method (AOAC Offical Method 966.24) for Enumeration of Escherichia Coli and Coliform Bacteria in Raw Meats. J. AOAC Int. 2006, 89 (1), 100-114.

(77) Andersen, A. A. New Sampler for the Collection, Sizing, and Enumeration of Viable Airborne Particles. U. S. Army Chem. Corps Proving Gr. 1958, 76 (904), 471-484.

(78) Bain, R. E. S.; Woodall, C.; Elliott, J.; Arnold, B. F.; Tung, R.; Morley, R.; Du Preez, M.; Bartram, J. K.; Davis, A. P.; Gundry, S. W.; et al. Evaluation of an Inexpensive Growth Medium for Direct Detection of Escherichia Coli in Temperate and Sub-Tropical Waters. PLoS One 2015, 10 (10), 113.

(79) Magro, G.; Bain, R. E. S.; Woodall, C. A.; Matthews, R. L.; Gundry, S. W.; Davis, A. P. Synthesis and Application of Resorufin $\beta$ - D -Glucuronide, a Low-Cost Chromogenic Substrate for Detecting Escherichia Coli in Drinking Water. Environ. Sci. Technol. 2014, 48 (16), 9624-9631.

(80) Genter, F.; Marks, S. J.; Clair-Caliot, G.; Mugume, D. S.; Johnston, R. B.; Bain, R. E. S.; Julian, T. R. Evaluation of the Novel Substrate RUG ${ }^{\mathrm{TM}}$ for the Detection of: Escherichia Coli in Water from Temperate (Zurich, Switzerland) and Tropical (Bushenyi, Uganda) Field Sites. Environ. Sci. Water Res. Technol. 2019, 5 (6), 1082-1091.

(81) Diaz, M. H.; Waller, J. L.; Theodore, M. J.; Patel, N.; Wolff, B. J.; Benitez, A. J.; Morris, T.; Raghunathan, P. L.; Breiman, R. F.; Whitney, C. G.; et al. Development and Implementation of Multiplex TaqMan Array Cards for Specimen Testing at Child Health and Mortality Prevention Surveillance Site Laboratories. 2019, 69 (Suppl 4), 311-321.

(82) Capone, D.; Berendes, D.; Cumming, O.; Knee, J.; Nalá, R.; Risk, B. B.; Stauber, C.; Zhu, K.; Brown, J. Analysis of Fecal Sludges Reveals Common Enteric Pathogens in Urban Maputo, Mozambique. Environ. Sci. Technol. Lett. 2020, 7 (12), 889-895.

(83) Kodani, M.; Winchell, J. M. Engineered Combined-Positive-Control Template for Real-Time Reverse Transcription-PCR in Multiple-Pathogen-Detection Assays. J. Clin. Microbiol. 2012, 50 (3), 1057-1060.

(84) Kotloff, K. L.; Nataro, J. P.; Blackwelder, W. C.; Nasrin, D.; Farag, T. H.; Panchalingam, S.; Wu, Y.; Sow, S. O.; Sur, D.; Breiman, R. F.; et al. Burden and Aetiology of Diarrhoeal Disease in Infants and Young Children in Developing Countries (the Global Enteric Multicenter Study, GEMS): A Prospective, Case-Control Study. Lancet 2013, 382 (9888), 209-222.

(85) Petri, W. A.; Miller, M.; Binder, H. J.; Levine, M. M.; Dillingham, R.; Guerrant, R. L. Enteric Infections, Diarrhea, and Their Impact On Function and Development. J. Clin. Invest. 2008, 118 (4).

(86) Levine, M. M.; Nasrin, D.; Acácio, S.; Bassat, Q.; Powell, H.; Tennant, S. M.; Sow, S. O.; Sur, D.; Zaidi, A. K. M.; Faruque, A. S. G.; et al. Diarrhoeal Disease and Subsequent Risk of Death in Infants and Children Residing in Low-Income and Middle-Income Countries: Analysis of the GEMS CaseControl Study and 12-Month GEMS-1A Follow-on Study. Lancet Glob. Heal. 2020, 8 (2), e204e214.

(87) Chopra, R. D.; Dworkin, M. S. Descriptive Epidemiology of Enteric Disease in Chennai, India. Epidemiol. Infect. 2013, 141 (5), 953-957.

(88) Eng, S. K.; Pusparajah, P.; Ab Mutalib, N. S.; Ser, H. L.; Chan, K. G.; Lee, L. H. Salmonella: A 
Review on Pathogenesis, Epidemiology and Antibiotic Resistance. Front. Life Sci. 2015, 8 (3), 284 293.

(89) Knight, A.; Haines, J.; Stals, A.; Li, D.; Uyttendaele, M.; Knight, A.; Jaykus, L. A. A Systematic Review of Human Norovirus Survival Reveals a Greater Persistence of Human Norovirus RTQPCR Signals Compared to Those of Cultivable Surrogate Viruses. Int. J. Food Microbiol. 2016, $216,40-49$.

(90) Taylor, S. C.; Laperriere, G.; Germain, H. Droplet Digital PCR versus QPCR for Gene Expression Analysis with Low Abundant Targets: From Variable Nonsense to Publication Quality Data. Sci. Rep. 2017, 7 (1), 1-8.

(91) Stokdyk, J. P.; Firnstahl, A. D.; Spencer, S. K.; Burch, T. R.; Borchardt, M. A. Determining the 95\% Limit of Detection for Waterborne Pathogen Analyses from Primary Concentration to QPCR. Water Res. 2016, 96, 105-113.

(92) Bivins, A.; Lowry, S.; Murphy, H. M.; Borchardt, M.; Coyte, R.; Labhasetwar, P.; Brown, J. Waterborne Pathogen Monitoring in Jaipur, India Reveals Potential Microbial Risks of Urban Groundwater Supply. npj Clean Water 2020, 3 (1).

(93) Seinfeld, J.; Pandis, S. Atmospheric Chemistry and Physics: From Air Pollution to Climate Change, 3rd ed.; Wiley: New Jersey, 2016.

(94) Flagan, R. C.; Seinfeld, J. H. Fundamentals of Air Pollution Engineering; Prentice-Hall, Inc.: Englewood Cliffs, New Jersey, 1988.

(95) Health and Ecological; Criteria Division, Office of Science and Technology, U. S. (U. S. . E.; (EPA), P. A. Recreational Water Quality Criteria; 2012.

(96) Lawrence, S. J. Escherichia Coli Bacteria Density in Relation to Turbidity, Streamflow Characteristics, and Season in the Chattahoochee River near Atlanta, Georgia, October 2000 through September 2008 - Description, Statistical Analysis, and Predictive Modeling. 2012, No. September $2008,81$.

(97) Troeger, C.; Blacker, B. F.; Khalil, I. A.; Rao, P. C.; Cao, S.; Zimsen, S. R.; Albertson, S. B.; Stanaway, J. D.; Deshpande, A.; Abebe, Z.; et al. Estimates of the Global, Regional, and National Morbidity, Mortality, and Aetiologies of Diarrhoea in 195 Countries: A Systematic Analysis for the Global Burden of Disease Study 2016. Lancet Infect. Dis. 2018, 18 (11), 1211-1228.

(98) Jahne, M. A.; Rogers, S. W.; Holsen, T. M.; Grimberg, S. J. Quantitative Microbial Risk Assessment of Bioaerosols from a Manure Application Site. Aerobiologia (Bologna). 2015, 31 (1), $73-87$.

(99) Jahne, M. A.; Rogers, S. W.; Holsen, T. M.; Grimberg, S. J.; Ramler, I. P. Emission and Dispersion of Bioaerosols from Dairy Manure Application Sites: Human Health Risk Assessment. Environ. Sci. Technol. 2015, 49 (16), 9842-9849.

(100) Seitz, S. R.; Leon, J. S.; Schwab, K. J.; Lyon, G. M.; Dowd, M.; McDaniels, M.; Abdulhafid, G.; Fernandez, M. L.; Lindesmith, L. C.; Baric, R. S.; et al. Norovirus Infectivity in Humans and Persistence in Water. Appl. Environ. Microbiol. 2011, 77 (19), 6884-6888.

(101) Cheesbrough, J. S.; Barkess-Jones, L.; Brown, D. W. Possible Prolonged Environmental Survival of Small Round Structured Viruses. J. Hosp. Infect. 1997, 35 (4), 325-326.

(102) Marks, P. J.; Vipond, I. B.; Regan, F. M.; Wedgwood, K.; Fey, R. E.; Caul, E. O. A School Outbreak of Norwalk-like Virus: Evidence for Airborne Transmission. Epidemiol. Infect. 2003, 131 (1), 727736. 
(103) Marks, P. J.; Vipond, I. B.; Carlisle, D.; Deakin, D.; Fey, R. E.; Caul, E. O. Evidence for Airborne Transmission of Norwalk-like Virus (NLV) in a Hotel Restaurant. Epidemiol. Infect. 2000, 124 (3), 481-487.

(104) O’Neill, P. D.; Marks, P. J. Bayesian Model Choice and Infection Route Modelling in an Outbreak of Norovirus. Stat. Med. 2005, 24 (13), 2011-2024.

(105) Alsved, M.; Widell, A.; Dahlin, H.; Karlson, S.; Medstrand, P.; Löndahl, J. Aerosolization and Recovery of Viable Murine Norovirus in an Experimental Setup. Sci. Rep. 2020, 10 (1), 1-10.

(106) Tung-Thompson, G.; Libera, D. A.; Koch, K. L.; De Los Reyes, F. L.; Jaykus, L. A. Aerosolization of a Human Norovirus Surrogate, Bacteriophage MS2, during Simulated Vomiting. PLoS One 2015, $10(8), 1-13$.

(107) Teunis, P.; Moe, C. L.; Liu, P.; Miller, S. E.; Lindesmith, L.; Baric, R. S.; Le Pendu, J.; Calderon, R. L. Norwalk Virus: How Infectious Is It? J. Med. Virol. 2008, 80, 1468-1476.

(108) Lopman, B.; Atmar, R.; Baric, R.; Estes, M.; Green, K.; Glass, R.; Hall, A.; Iturriza-Gomara, M.; Kang, C.; Lee, B.; et al. Global Burden of Norovirus and Prospects for Vaccine Development Table of Contents. 2015.

(109) Ahmed, S. M.; Hall, A. J.; Robinson, A. E.; Verhoef, L.; Premkumar, P.; Parashar, U. D.; Koopmans, M.; Lopman, B. A. Global Prevalence of Norovirus in Cases of Gastroenteritis: A Systematic Review and Meta-Analysis. Lancet Infect. Dis. 2014, 14 (8), 725-730.

(110) Igbinosa, I. H.; Igumbor, E. U.; Aghdasi, F.; Tom, M.; Okoh, A. I. Emerging Aeromonas Species Infections and Their Significance in Public Health. Sci. World J. 2012, 2012.

(111) Fernández-Bravo, A.; Figueras, M. J. An Update on the Genus Aeromonas: Taxonomy, Epidemiology, and Pathogenicity; 2020; Vol. 8.

(112) Balderrama-Carmona, A. P.; Gortáres-Moroyoqui, P.; Álvarez-Valencia, L. H.; Castro-Espinoza, L.; Mondaca-Fernández, I.; Balderas-Cortés, J. de J.; Chaidez-Quiroz, C.; Meza-Montenegro, M. M. Occurrence and Quantitative Microbial Risk Assessment of Cryptosporidium and Giardia in Soil and Air Samples. Int. J. Infect. Dis. 2014, 26, 123-127.

(113) Rocha-Melogno, L.; Ginn, O.; Bailey, E. S.; Soria, F.; Andrade, M.; Bergin, M. H.; Brown, J.; Gray, G. C.; Deshusses, M. A. Bioaerosol Sampling Optimization for Community Exposure Assessment in Cities with Poor Sanitation: A One Health Cross-Sectional Study. Sci. Total Environ. 2020, 738.

(114) Salazar, D.; Ginn, O.; Brown, J.; Soria, F.; Garvizu, C. Assessment of Antibiotic Resistant Coliforms from Bioaerosol Samples Collected above a Sewage-Polluted River in La Paz, Bolivia. Int. J. Hyg. Environ. Health 2020, 228 (November 2019), 113494.

(115) Medina, C.; Ginn, O.; Brown, J.; Soria, F.; Garvizu, C.; Salazar, D.; Tancara, A.; Herrera, J. Detection and Assessment of the Antibiotic Resistance of Enterobacteriaceae Recovered from Bioaerosols in the Choqueyapu River Area, La Paz - Bolivia. Sci. Total Environ. 2020, No. xxxx, 143340.

(116) Odonkor, S. T.; Ampofo, J. K. Escherichia Coli as an Indicator of Bacteriological Quality of Water: An Overview. Microbiol. Res. (Pavia). 2013, 4 (1), 2.

(117) Bagley, S. T.; Auer, M. T.; Stern, D. A.; Babiera, M. J. Sources and Fate of Giardia Cysts and Cryptosporidium Oocysts in Surface Waters. Lake Reserv. Manag. 1998, 14 (2-3), 379-392.

(118) Lemarchand, K.; Lebaron, P. Occurrence of Salmonella Spp. and Cryptosporidium Spp. in a French Coastal Watershed: Relationship with Fecal Indicators. FEMS Microbiol. Lett. 2003, 218 (1), 203- 
209.

(119) Duchaine, C. Assessing Microbial Decontamination of Indoor Air with Particular Focus on Human Pathogenic Viruses. Am. J. Infect. Control 2016, 44 (9), S121-S126.

(120) Haig, C. W.; Mackay, W. G.; Walker, J. T.; Williams, C. Bioaerosol Sampling: Sampling Mechanisms, Bioefficiency and Field Studies. J. Hosp. Infect. 2016, 93 (3), 242-255.

(121) Pan, M.; Lednicky, J. A.; Wu, C. Y. Collection, Particle Sizing and Detection of Airborne Viruses. J. Appl. Microbiol. 2019, 127 (6), 1596-1611.

(122) Contreras, J. D.; Trangucci, R.; Felix-Arellano, E. E.; Rodríguez-Dozal, S.; Siebe, C.; RiojasRodríguez, H.; Meza, R.; Zelner, J.; Eisenberg, J. N. S. Modeling Spatial Risk of Diarrheal Disease Associated with Household Proximity to Untreated Wastewater Used for Irrigation in the Mezquital Valley, Mexico. Environ. Health Perspect. 2020, 128 (7), 1-9.

(123) Kouimtzi, M.; Pinney, R. J.; Newton, J. M. Survival of Bacteria during Extrusion-Spheronization. Pharm. Sci. 1997, 3 (7), 347-351.

(124) Yoo, K.; Lee, T. K.; Choi, E. J.; Yang, J.; Shukla, S. K.; Hwang, S. il; Park, J. Molecular Approaches for the Detection and Monitoring of Microbial Communities in Bioaerosols: A Review. J. Environ. Sci. (China) 2017, 51, 234-247.

(125) Alburty Lab. Dry Filter Collection / Wet Elution Aspiration and Recovery Efficiency Testing; 2013.

(126) Lednicky, J. A.; Lauzardo, M.; Fan, Z. H.; Jutla, A. S.; Tilly, T. B.; Gangwar, M.; Usmani, M.; Shankar, S. N.; Mohamed, K.; Eiguren-Fernandez, A.; et al. Viable SARS-CoV-2 in the Air of a Hospital Room with COVID-19 Patients. medRxiv 2020, No. 1, 1-20.

(127) Thye, Y. P.; Templeton, M. R.; Ali, M. A Critical Review of Technologies for Pit Latrine Emptying in Developing Countries. Crit. Rev. Environ. Sci. Technol. 2011, 41 (20), 1793-1819.

(128) Pagalilauan, H. A. M.; Paraoan, C. E. M.; Vital, P. G. Detection of Pathogenic Bioaerosols and Occupational Risk in a Philippine Landfill Site. Arch. Environ. Occup. Heal. 2018, 73 (2), 107-114.

(129) Yu, Y.; Yu, Z.; Sun, P.; Lin, B.; Li, L.; Wang, Z.; Ma, R.; Xiang, M.; Li, H.; Guo, S. Effects of Ambient Air Pollution from Municipal Solid Waste Landfill on Children's Non-Specific Immunity and Respiratory Health. Environ. Pollut. 2018, 236, 382-390.

(130) Bøifot, K. O.; Gohli, J.; Skogan, G.; Dybwad, M. Performance Evaluation of High-Volume Electret Filter Air Samplers in Aerosol Microbiome Research. Environ. Microbiomes 2020, 15 (1), 1-16.

(131) Brown, J.; Cairncross, S.; Ensink, J. H. J. Water, Sanitation, Hygiene and Enteric Infections in Children. Arch. Dis. Child. 2013, 98 (8), 629-634.

(132) Penakalapati, G.; Swarthout, J.; Delahoy, M. J.; McAliley, L.; Wodnik, B.; Levy, K.; Freeman, M. C. Exposure to Animal Feces and Human Health: A Systematic Review and Proposed Research Priorities. Environ. Sci. Technol. 2017, 51 (20), 11537-11552.

(133) Robb, K.; Null, C.; Teunis, P.; Yakubu, H.; Armah, G.; Moe, C. L. Assessment of Fecal Exposure Pathways in Low-Income Urban Neighborhoods in Accra, Ghana: Rationale, Design, Methods, and Key Findings of the Sanipath Study. Am. J. Trop. Med. Hyg. 2017, 97 (4), 1020-1032. 